\title{
7000 ÉVES DÉL-MAGYARORSZÁGI TUBERKULÓZIS ESETEK OSZTEOLÓGIAI ÉS MOLEKULÁRIS BIOLÓGIAI VIZSGÁLATA
}

\author{
Muriel Masson ${ }^{1}$, Bereczki Zsolt ${ }^{1}$, Molnár Erika ${ }^{1}$, Helen D. Donoghue ${ }^{2}$, \\ David E. Minnikin ${ }^{3}$, Oona Y-C. Lee ${ }^{3}$, Houdini H. T. Wu ${ }^{3}$, Gurdyal S. Besra ${ }^{3}$, Ian D. Bull ${ }^{4}$ \\ és Pálfi György ${ }^{1}$ \\ ${ }^{1}$ Szegedi Tudományegyetem, Embertani Tanszék, Szeged; ${ }^{2}$ University College London, Centre for \\ Clinical Microbiology and Centre for the History of Medicine, London, UK; ${ }^{3}$ University of \\ Birmingham, School of Biosciences, Institute of Microbiology and Infection, Birmingham, UK; \\ ${ }^{4}$ University of Bristol, School of Chemistry, Organic Geochemistry Unit, Bristol, UK
}

Masson, M., Bereczki Zs., Molnár E., Donoghue, H. D., Minnikin, D. E., Lee, O. Y-C., Wu, H. H. T., Besra, G. S., Bull, I. D., Pálfi Gy.: Osteological and biomolecular analysis of 7000-year-old tuberculosis cases from Southern Hungary. This study derives from the macroscopic analysis of a Late Neolithic population from southern Hungary. Remains were recovered from a tell settlement at Hódmezövásárhely-Gorzsa from graves within the settlement as well as pits, ditches, houses and as stray finds. Pathological analysis of the 71 individuals revealed numerous cases of infections and non-specific stress indicators, metabolic diseases, and evidence of trauma and mechanical changes. Several cases showed potential signs of tuberculosis and further analyses were undertaken, including biomolecular studies. The five individuals were all very young adults and included a striking case of hypertrophic pulmonary osteopathy. The initial macroscopic diagnosis of these five cases was confirmed by lipid biomarker analyses, and three of them were corroborated by DNA analysis. At present, these 7000-year-old individuals are among the oldest palaeopathological and palaeomicrobiological cases of tuberculosis worldwide.

Keywords: Tuberculosis; Neolithic; aDNA; Lipid biomarkers; Southern Hungary.

\section{Bevezetés}

Tanulmányunk vizsgálati anyagát a hódmezővásárhely-gorzsai késő neolitikus tell ásatásai során előkerült emberi maradványok képezik. A lelőhely Hódmezővásárhelytől 15 km-re délnyugatra található (1. ábra), és hat településréteggel rendelkezik a korai tiszai kultúrától kezdődően. A természetes magaslaton található települést egykor vízfolyások és mocsarak vették körül.

A tiszai kultúra megtelepedése a Kr. e. 5. évezred első felében kezdődött és legalább 3 évszázadon át tartott a lelőhelyen. A lelőhelyről származó 12 minta radiokarbonos kormeghatározása Kr. e. 4970-4594 közé eső kalibrált értékeket eredményezett (Hertelendi és Horváth 1992), melyeket nemrégiben Masson újrakalibrált, és a használati periódust 95,4\% konfidencia intervallummal Kr. e. 4932-4602 közötti időszakra módosította (északi féltekére vonatkozó IntCal04 kalibrációs görbe, OxCal 4.1 program; Masson 2014). A HGO-53-as kódszámú (jelen tanulmányunkban is szereplő) egyén csontmaradványainak kormeghatározása szintén a közelmúltban zajlott le Debrecenben a MTA Atommagkutató Intézetének Hertelendi Ede Környezetanalitikai Laboratóriumában egy AMS C-14 készülék segítségével (AMS Lab code DeA-2485.1.1), az eredmény pedig 
megerösítette a korábbi adatokat: eszerint a HGO-53 maradványai a Kr. e. 5. évezred elejéről származnak, a Kr. e. 4780-4715-as (kalibrált, 1 szigma) időszakból (Kr. e. 5872+32 év kalibrálatlan, intcal09.14c; Reimer és mtsai 2009).

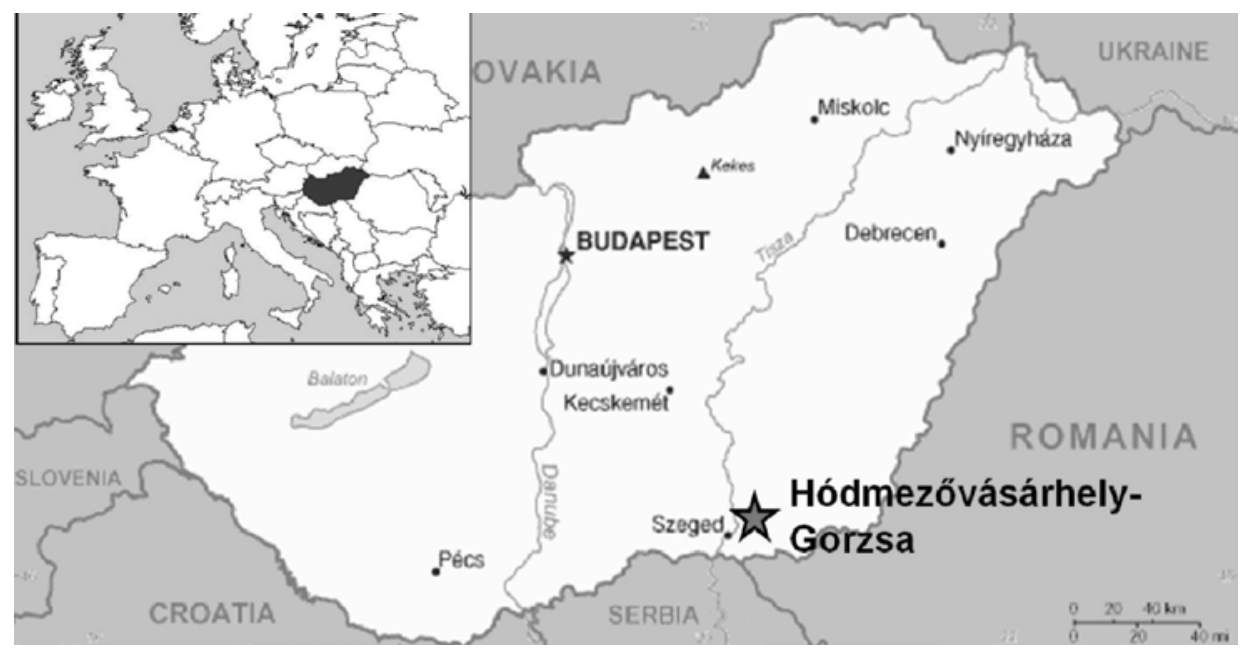

1. ábra: A hódmezővásárhely-gorzsai késő neolitikus tell földrajzi elhelyezkedése. A lelőhely Hódmezővásárhelytől mintegy $15 \mathrm{~km}$-re délnyugatra található.

Fig. 1: Location of the site. The Late Neolithic tell settlement of Hódmezővásárhely-Gorzsa is located about $15 \mathrm{~km}$ southwest of Hódmezővásárhely.

A lelőhelynek eddig csupán kb. 2\%-a került feltárásra. Az első ásatásokat Gazdapusztai (1963) vezette az ötvenes években, később Horváth irányításával folyt tovább a feltárás a hetvenes, nyolcvanas és a kilencvenes években (Horváth 2005). A lelőhely részletes régészeti adatainak publikálására a közeljövőben fog sor kerülni.

Hódmezővásárhely-Gorzsa lelöhelyről eddig 71 tiszai kultúrához köthető egyén maradványa került elő, amelyek közül 56 a település területén belül elhelyezkedő sírokból származik, és további 15 egyén hiányos maradványai kerültek elő különböző gödrökből, árkokból, házakból és szórványleletként. Jelenleg a csontmaradványok a Szegedi Tudományegyetem (SZTE) Embertani Tanszékének oszteoarcheológiai gyüjteményében találhatók. Az emberi maradványok paleopatológiai vizsgálata során összesen öt, makromorfológiai tüneteket mutató lehetséges tuberkulózisos eset került elő, amelyeket DNS és lipid biomarker analízisnek vetettük alá. Jelen tanulmányunkban ezeket a közel 7000 éves tbc-s eseteket mutatjuk be, amelyeket pillanatnyilag a tbc legrégebbi bizonyított európai előfordulásai között tarthatunk számon.

\section{Anyag és módszer}

Makromorfológiai elemzés

A Hódmezővásárhely-Gorzsa lelőhelyről származó 71 késő neolit-kori emberi vázmaradvány az SZTE Embertani Tanszékén található, ahol a makroszkópos morfológiai vizsgálatokra sor került. A leletek tanulmányunkban szereplő kódszámai nem az eredeti sírszámokat jelölik, azok valós sírszámokkal, ill. objektumszámokkal való egyeztetése a 
lelőhely régészeti publikálása után válik majd lehetségessé. Valamennyi tanulmányozott csontvázlelet megtartási állapota töredékesnek mondható. A nemiség meghatározása során többféle morfológiai módszert is alkalmaztunk, különös hangsúlyt helyezve a koponya és a medence jellegzetességeire, kisebb részben pedig a csontok méretarányaira támaszkodva (Loth és Henneberg 1996, White és Folkens 2005). Az elhalálozási életkor becslését a csontváz és a fogazat fejlettsége alapján végeztük, az epifízisfúgák záródására, a fogkopásra, valamint a szeméremcsont és a facies auricularis változásaira való tekintettel (Brothwell 1989, Schaefer és mtsai 2009). A paleopatológiai elváltozásokat (pl. 2-4. ábra) a paleopatológiai diagnosztika klasszikus elvei szerint, a vonatkozó általános vagy specifikus szakirodalom felhasználásával értékeltük (Pálfi és mtsai 1999, Ortner 2003).

A makromorfológiai vizsgálatok szerint a teljes késő neolit széria közel harmada gyermekkorú egyén maradványa volt. A többi maradvány közül a meghatározható nemüek majdnem két harmada nőnek bizonyult. Ebben a közösségben feltehetően ritkán fordultak elő erőszakos cselekmények, azonban az erős fizikai stressz nyomai jól megfigyelhetők a maradványokon, a fertőzésekre is hajlamosak voltak, és körükben gyakran előfordultak különböző fogazati rendellenességek is (Masson és mtsai 2009). A patológiai elemzés során elökerült egy hipertrófiás pulmonális osteopathia eset (HPO; régebbi elnevezéssel hipertrófiás pulmonális osteo-artropathia (HPOA), hipertrófiás osteo-artropathia (HOA), ill. Pierre-Marie-Bamberger szindróma). Ez a kórkép manapság leggyakrabban mellkasi tumorok, krónikus mellkasi fertőzések, ritkábban tbc tüneteként jelentkezik (Rothschild és Rothschild 1998, Ntaios és mtsai 2008, Munoz és mtsai 2015), a régmúltban azonban a tuberkulózis még nagyobb valószínűséggel okozhatott ilyen elváltozásokat. Egy korábbi bioarcheológiai tanulmány már sikeresen bizonyította, hogy két középkori leletnél megfigyelt HPO lehetséges elsődleges oka tuberkulózis lehetett (Mays és Taylor 2002). Az is bebizonyosodott, hogy a tuberkulózis és a HPO előfordulása az antibiotikumok felfedezése előtti történeti korokban erősen korrelál (Assis és mtsai 2011). A modern klinikumban a HPO súlyos és kezeletlen pulmonális tuberkulózis tüneteként fordul elő (Webb és Thomas 1986). Esetünkben, a HPO és a tuberkulózis felmerülő szoros kapcsolatára való tekintettel, az érintett egyén maradványain Mycobacterium tuberculosis (MTB) DNS és Mycobacterium-fajspecifikus lipid biomarker analízist végeztünk. A vizsgálatokba további négy egyén maradványait is bevontuk, amelyek szintén mutattak tuberkulózisra utaló makromorfológiai tüneteket.

DNS elemzés

A DNS elemzésre a University College London Orvosi Mikrobiológia Tanszékén került sor, ahol rendkívül nagy tapasztalattal rendelkeznek a Mycobacterium tuberculosis DNS-vizsgálatának területén. A vizsgálatok során gondosan követtük az irodalomban ajánlott protokollt, és minden vizsgált borda, illetve csigolya mintából kb. 55 mg csontport vettünk. A DNS extrakció (Hershkovitz és mtsai 2008, Donoghue és mtsai 2010) után PCR-ral amplifikáltuk a specifikus DNS-szakaszokat (a M. tuberculosis complex genomra jellemző ismétlődő IS6110 és IS1081 inzerciós szekvenciákat). Az amplifikált DNS-t először agaróz gélelektroforézissel futtattuk, majd Real-Time platformot alkalmaztunk, hogy az ún. SYBR Green and melt analízis segítségével detektálhassuk a DNS-t (Hajdu és mtsai 2012a). A Real-Time platform alkalmazása, a kettős inzerciós szekvencia tesztelés (IS 6110 + IS 1081) a nagyobb fokú diagnosztikus pontosság miatt történt (Donoghue és mtsai 2015), tekintettel az egyszerü PCR tesztek 
utóbbi években kimutatott, bizonyos specificitási problémáira (Coros és mtsai 2008, Müller és mtsai 2015). Ezt követően a bakteriális DNS szekvenáltatására került sor. Az alkalmazott teljes protokoll korábban már publikálásra került (Masson és mtsai 2013, 2015).

\section{Lipid biomarker elemzés}

A lipid biomarkerek vizsgálata jól kiegészíti a múltbeli tbc-fertőzések DNS alapú diagnosztikáját (Hershkovitz és mtsai 2008, Redman és mtsai 2009, Donoghue és mtsai 2010). A sejtfalalkotó lipidek (mikolátok, mikocerozátok, mikolipenátok) esetében nincs szükség az amplifikálásra, és szennyeződésre is kevésbé hajlamosak (Hershkovitz és mtsai 2008, Lee és mtsai 2012, Minnikin és mtsai 2015). Bár a mikolsavak degradálódhatnak a régi emberi maradványokban, a mikocerozátok jóval stabilabbak és ellenállóbbak (Lee és mtsai 2012). A lipid biomarkereket extraháltuk, derivatizáltuk és frakcionáltuk a korábban már részletesen publikált módszerek segítségével (Hershkovitz és mtsai 2008, Lee és mtsai 2012, Masson és mtsai 2013, 2015).

\section{Vizsgálati eredmények}

HGO-53, fiatal felnött, kb. 19-20 éves életkorban elhalálozott férfi csontvázmaradványa. Az esetet korábban már ismertették (Masson és mtsai 2013). Patológiás elváltozások figyelhetők meg a koponyán, a mellkason, a teljes felső végtagon, a gerincen és az alsó végtagon. A szembeötlően szimmetrikus elhelyezkedésű diffúz periosztitisz nyomai és az aktív perioszteális újcsontképződés (2-3. ábra) hipertrófiás pulmonális osteopathiára (HPO) utalnak. Emellett a mellkas bal oldalán bordaelváltozások, a csigolyatesteken üregképződmények, a koponyán pedig porotikus hiperosztózis nyomai is megfigyelhetők. A töredékes maradványokból csak nagy nehézségek árán sikerült DNS-t kivonni. Az elemzés során Mycobacterium tuberculosisra specifikus töredékszekvenciát találtunk, amely igen rossz minőségü volt. Az M. tuberculosis-ra specifikus primer segítségével végrehajtott PCR egy 113 bázispár hosszúságú amplikont eredményezett. Ugyanezen maradványok lipid biomarker analízise tipikus, M. tuberculosis-ra jellemző mikocerozát profilt, valamint egy gyenge, degradálódott mikolát jelet adott (Masson és mtsai 2013, 2015).

HGO-08, 17-22 éves fiatal nő maradványai. Mindkét orbitában enyhe cribra orbitalia figyelhető meg. Reszorptív léziók figyelhetők meg az 5.-től a 12.-ig valamennyi hátcsigolya elülső oldalán és két ágyéki csigolyán is. A 7.-től a 12.-ig mindegyik hátcsigolyán Schmorl-csomók találhatók. Nagy kiterjedésű elváltozás figyelhető meg az első ágyékcsigolya alsó és a második ágyékcsigolya felső véglemezén, amelyek környezetében csontajakképzödés is látható. A tünetek M. tuberculosis fertőzéssel összefüggő eredetét megerősítette a lipid biomarker analízis (erős mikocerozátjel - 5. ábra, tiszta mikolátjel - 6. ábra; Lee és mtsai 2012).

HGO-10, húszas évei elején járó férfi csontmaradványai. Hipervaszkularizáció figyelhető meg öt egymást követő hátcsigolya elülső oldalán (üregek és árkok), valamint két ágyéki csigolyán is (üregek). Kismértékü perioszteális újcsontképződés és enyhe hipervaszkularizáció látható a bordák viszcerális felszínén (4A. ábra). A fogak felszínein lineáris zománc-hypoplasia nyomait figyelhetjük meg. A lipid biomarker analízis megerősítette a lelet tbc-s fertőzöttségét, és a csontelváltozások vélelmezhetően gümőkóros eredetét (erős mikocerozátjel - 5. ábra, tiszta mikolátjel - 6. ábra; Lee és mtsai 2012). 


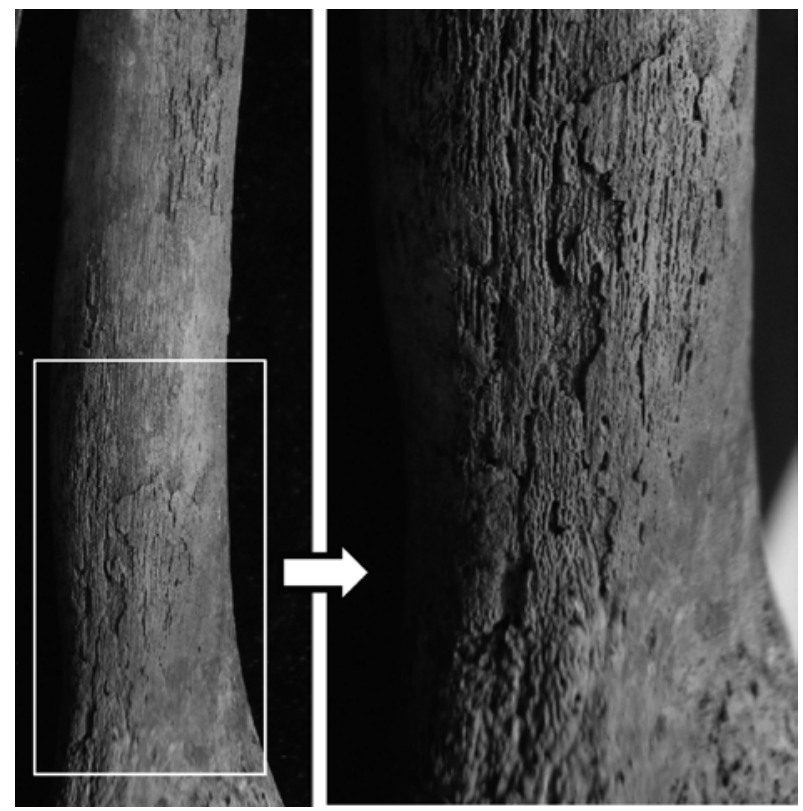

2. ábra: HGO-53 - Aktív fázisban lévő perioszteális újcsontképződés nyomai jobb ulnán. A folyamat bilaterális és szimmetrikus.

Fig. 2: HGO-53 - Active diffuse periostitis on the right ulna. The periostitis was bilateral and symmetrical.

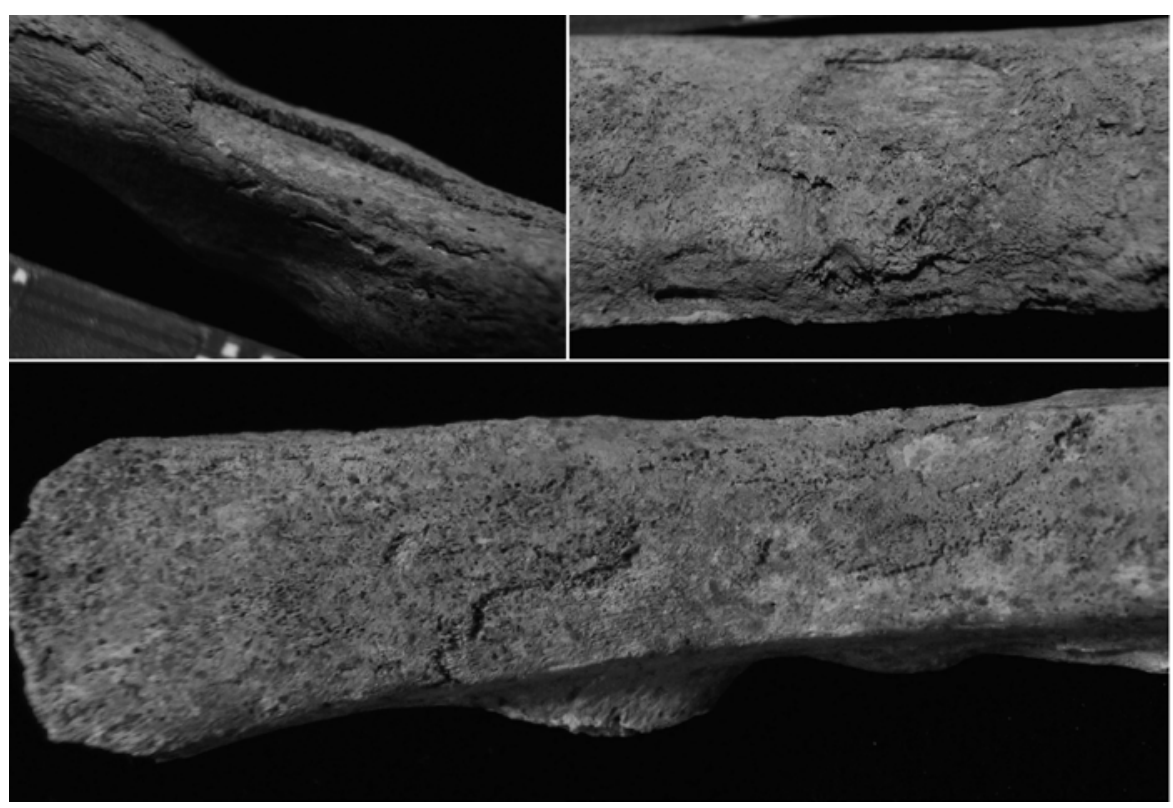

3. ábra: HGO-53 - Aktív diffúz perioszteális újcsontképződés nyomai bordákon. Fig. 3: HGO-53 - Active diffuse periostitis with extensive bone formation on the ribs. 


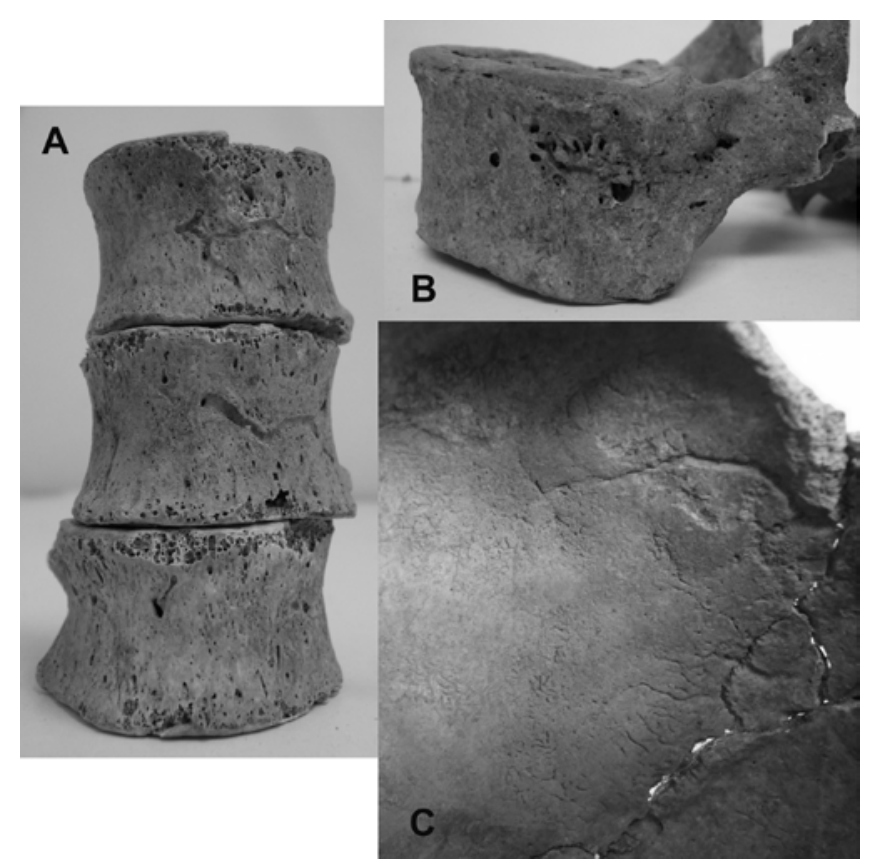

4. ábra: A tbc atipikus (vagy korai stádiumú) oszteológiai megjelenési formái. A: Csigolyahipervaszkularizáció a HGO-10-es csontvázon. B: Reszorptív elváltozás HGO-21 csigolyáján. C: SES-jellegü (serpens endocrania symmetrica) rendellenes érbenyomatok HGO-48 endokraniális felszínén.

Fig. 4: Atypical (or early-stage) osteological evidence of tuberculosis. A: Hypervascularisation of the vertebrae of HGO-10. B: Resorptive lesion on vertebra of HGO-21. C: Abnormal blood vessel impressions with SES-like pattern (serpens endocrania symmetrica) on the endocranial surface of HGO-48.

HGO-21, húszas évei elején járó nő maradványai. Az endokraniális felszínen kisméretü bemélyedések láthatók. A 9. hátcsigolyán megfigyelhető reszorptív elváltozások (4B. ábra), az egyik borda ventrális oldalán látható hipervaszkularizáció és két bordatöredék szternális végének külső felszínén található enyhe periosztitisz, valamint a cribra orbitalia mind felvetik a tbc-s folyamat lehetőségét. Ezt a felvetést alátámasztotta az erős mikocerozát profil (5. ábra), a gyenge mikolátjel (6. ábra) és a DNS analízis eredménye is (7. ábra).

HGO-48, fiatal felnőtt nő. A homlokcsont endokraniális felszínének nagyobb részén rendellenes, SES-jellegü (serpens endocrania symmetrica) érbenyomatok találhatók (4C. ábra), amely fertőzéses eredetủ meningitiszre, metabolikus rendellenességre, ill. tuberkulózisra utalhat (Hershkovitz és mtsai 2002). A jobb falcsont endokraniális felszínén látható nagyméretü, kb. 1 cm-es kerek benyomat szintén utalhat tuberkulózisra. A bal orbitában rendkívül enyhe cribra orbitalia figyelhető meg. Az erös mikocerozát profil (5. ábra) és a pozitív DNS-teszt (7. ábra) alátámasztják a M. tuberculosis fertőzés gyanúját, de a mikolsavjel nagyon gyenge volt (6. ábra). 

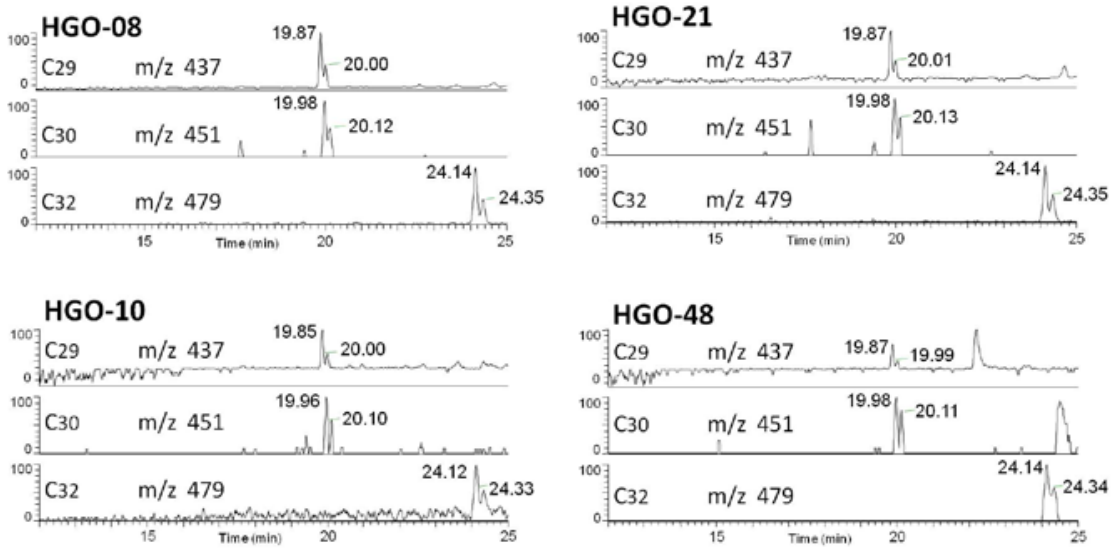

5. ábra: Mikocerozát profilok. Mikocerozátok pentafluorobenzil-észtereinek negatív ionozációs gázkromatográfiai (NI-CI GC-MS) profilja. A m/z 437, 451 és 479 pozícióba látható diagnosztikus jelek megfelelnek a C29, C30 és C32-es mikocerozátok karboxilát ionjainak. A mikocerozátokat a racemizációt követően kettős csúcs formájában lehet felismerni.

Fig. 5: Mycocerosate profiles. Negative ion chemical ionisation gas chromatography (NI-CI GCMS) profiles of pentafluorobenzyl esters of mycocerosic acids. The diagnostic signals at $\mathrm{m} / \mathrm{z} 437$,

451 and 479 correspond to the carboxylate ions, identified by selected ion monitoring, derived from C29, C30 and C32 mycocerosates. The mycocerosates are recognisable by their appearance as double peaks following racemisation.

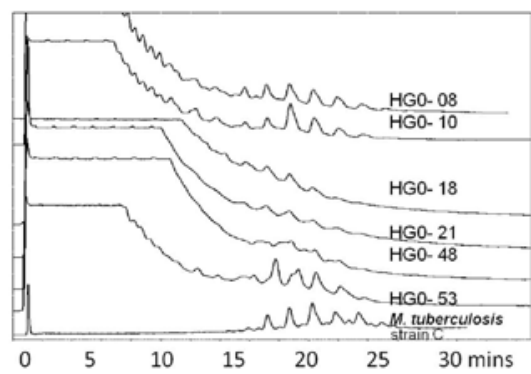

6. ábra: Mikolát profilok. Az összmikolsav-tartalom pirénbutiril-pentafluorobenzil (PBA-PFB) derivátumainak reverz fázisú fluorescens magas teljesítményü folyadékkromatográfiája, valamennyi csontmintán és a M. tuberculosis standardon. (Az összehasonlításul szolgáló HGO-18-as minta egy nem újkőkori gorzsai maradványból származik.)

Fig. 6: Mycolate profiles. Reverse phase fluorescence high performance liquid chromatography of total mycolic acid pyrenebutyryl pentafluorobenzyl (PBA-PFB) derivatives for extracts of all samples and standard M. tuberculosis. (HGO-18 is a non Neolithic specimen from the same burial site, which was included for comparison.) 

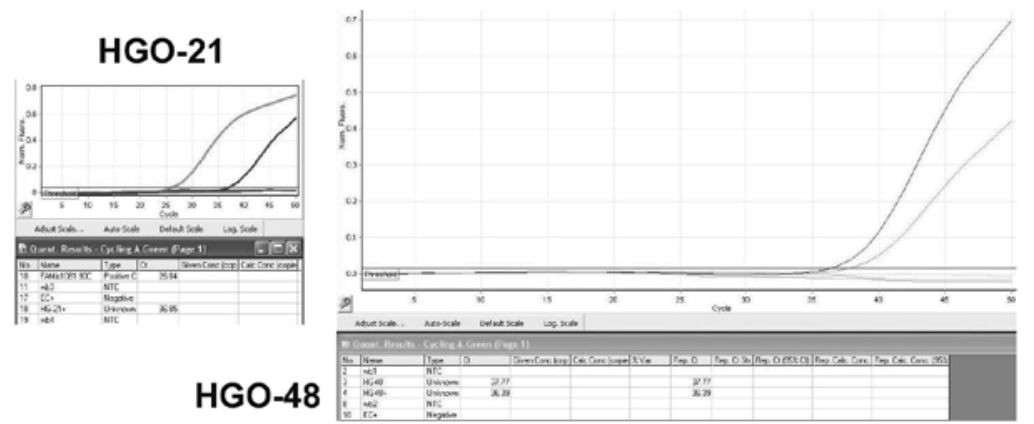

7. ábra: Az aDNS elemzés - M. tuberculosis komplex IS1081-es régiójára specifikus primerek és fluorescens próba - előzetes eredményei (az eredmény a HGO-53-asnál használt hagyományos szekvenáláshoz hasonlóan megerősíti a feltételezést, de alkalmasabb töredékes DNS vizsgálatára, mivel egy rövidebb, 72bp hosszúságú szekvenciára van kifejlesztve). +: a DNS extrakció során PTB-t is alkalmaztunk (DNS-szálak szétválását elősegítendő).

Fig. 7: Initial results of aDNA analysis, M. tuberculosis complex region IS1081 specific primers and fluorescent probe were used (as confirmatory as the more traditional sequencing used for

HGO-53 but better suited to fragmentary DNA as this probe target a shorter $72 \mathrm{bp}$ sequence). +: the DNA extraction included treatment with PTB (to enhance strand separation of the DNA).

\section{Eredmények megvitatása és következtetések}

A közelmúltig a mintegy 9000 éves izraeli Atlit Yam lelőhelyről származó 25 év körüli nő és kb. 12 hónapos gyermek maradványai szolgáltatták a legrégebbi olyan emberi maradványokat, amelyekből DNS és lipid biomarker elemzés segítségével sikerült kimutatni a tuberkulózis előfordulását (Hershkovitz és mtsai 2008). Ezeken a csontvázakon a fertőzésnek alig volt megfigyelhető oszteológiai nyoma: a felnött nő maradványai csak enyhe SES-szerü endokraniális elváltozásokat mutattak, míg a gyermekcsontváz hosszú csontjain enyhe periosztitisz maradványait fedezték fel a kutatók. Hershkovitz és munkatársainak munkája (2008) elött a legrégebbi elfogadott, oszteológiai adatokkal alátámasztott tuberkulózisos esetek a Kr. e. 4. évezredböl származó európai neolit esetek voltak (Formicola és mtsai 1987, Canci és mtsai 1996, Gladykowska-Rzeczycka 1999), míg a legrégebbi, DNS elemzéssel nyert adatok a predinasztikus Egyiptomból származtak (Kr. e. 3500-2650; Zink és mtsai 2007). Jelenleg a világon ismert legidősebb, makromorfológiai és biomolekuláris adatokkal is bizonyított tbc-s esetek közel 11 ezer éves szíriai lelőhelyekről származnak (Baker és mtsai 2015).

A hazai paleopatológia több évtizedes munkával százas nagyságrendben tárt fel emberi maradványokon régi tbc-s eseteket. Egészen a közelmúltig azonban csak a római korból, és annál fiatalabb régészeti korú leletekből sikerült izolálni a betegség nyomait (pl. Pálfi és mtsai 1999, Marcsik és mtsai 2009, Hajdu és mtsai 2012b). Történelmi áttörést jelentett, amikor 2012-ben Magyarországon őskori gümőkóros beteget azonosítottak: abban az évben közöltek egy spondylitis tuberculosa (Pott-gibbus) esetet Alsónyék-Bátaszék késő neolit-kora rézkori (Kr. e. 5. évezred) temetöjéből (Köhler és mtsai 2012). A morfológiai jellegek egyértelmüen elörehaladott gerinctuberkulózisra utaltak, később pedig a pozitív DNS-vizsgálat eredményeit is publikálták (Pósa és mtsai 2015). Ugyanabban az évben további lehetséges őskori tuberkulózisos esetek kerültek elő 
a mintegy 5000 éves vésztő-mágori lelőhelyröl (Spekker és mtsai 2012), ahol egy esetben szintén sikerült kimutatni a M. tuberculosis DNS-ét fogmintából (Pósa és mtsai 2012).

Jelen tanulmányunkban különböző módszerek (makromorfológia, DNS és lipid biomarkerek elemzése) sikeres kombinálásával kimutattuk a Mycobacterium tuberculosis jelenlétét egy közel 7000 éves lelöhely több emberi maradványán. A lipid biomarkerek közül különösen az ellenálló mikocerozátok kitünő diagnosztikus felhasználhatóságát kell kiemelnünk, ami különösen jól alkalmazhatóvá teszi ezeket a markereket öskori tuberkulózisos esetek bizonyítására (Lee és mtsai 2012, Masson és mtsai 2015). Ez idő szerint Hódmezővásárhely-Gorzsa közel 7000 éves esetei a gümőkór előfordulásának legősibb bizonyított adatait a Kárpát-medencéből, és egyúttal Európából is. A bemutatott öskori paleopatológiai leleteinket időben egyelőre csak a 9000 éves izraeli (Hershkovitz és mtsai 2009) és 11000 éves szíriai leletek (Baker és mtsai 2015) előzik meg.

Fontos megjegyeznünk, hogy az öt, morfológiai és molekuláris módszerekkel is igazolt újkőkori tbc-s megbetegedés aránylag magas szám a széria viszonylag kis leletszámához képest (71 lelet), hiszen a tbc csak az antibiotikum felfedezését megelöző időben csupán az összes gümőkóros megbetegedés 5-7\%-ában okozott csonttani tüneteket (Aufderheide és Rodriguez-Martin 1998, Ortner 2003). Valószínü, hogy a hódmezővásárhely-gorzsai őskori embertani széria a közeljövőben is a tudományos érdeklődés középpontjában marad, mivel a bemutatott eseteken kívül további lehetséges tuberkulózisos eseteket is tartalmaz, utalva a betegség jelentős őskori gyakoriságára, és a számos egyéb megfigyelt kóros elváltozással együttesen (Masson 2014) rávilágítva a prehisztorikus közösségek életének nehézségeire.

Tanulmányunk arra is rámutat, hogy a tuberkulózis paleopatológiai vizsgálata során fontos eltekinteni a modern klinikai diagnosztikai kritériumok kizárólagos használatától, hiszen a betegségfolyamatok az idő során változhattak. Klasszikus tuberkulózisos csontváz-tünetek közé soroljuk a csigolyák összeroppanását és fúzióját, amely Pottgibbushoz vezet, a térdízület krónikus tbc-s gonitiszt követő fúzióját, a csípőízület destrukcióját, vagy pl. a csigolyákon és a keresztcsonton megfigyelhető hidegtályognyomokat, spina ventosa vagy más, tipikus tbc-s oszteitisszel együtt járó tüneteket. Tuberkulózisra utalhatnak azonban olyan csonttani elváltozások is, mint a bordákon megfigyelhető perioszteális újcsontképződés, a csigolyatesteken megfigyelhetö hipervaszkularizáció és egyéb felszíni elváltozások, a diffúz szimmetrikus periosztitisz (HPO), serpens endocrania symmetrica és más rendellenes endokraniális elváltozások (Maczel és mtsai 2003, Matos és Santos 2006, Pálfi és mtsai 2012). A gorzsai anyagban valamennyi itt felsorolt atipikus tünet előfordult a biomolekuláris módszerekkel is alátámasztott tbc-s esetek között. Ezzel szemben egyetlen klasszikus tuberkulózisra utaló jelet sem tapasztaltunk. A porotikus hiperosztózisok nemcsak a vashiányos vérszegénység jól ismert tünetei lehetnek, hanem számos más faktor egyedüli vagy kombinált hatása is befolyásolhatja megjelenésüket (szoptatási szokások, étrend, higiénia, paraziták, fertőzések, stb.), így előfordulhatnak tuberkulózis kíséröjelenségeként is.

A dolgozatunkban bemutatott öskori tuberkulózis esetek kiemelt figyelmet érdemelnek: paleopatológiai érdekességükön túl arra is rámutatnak, hogy a kevésbé tipikus és nyilvánvaló csontízületi tbc-tüneteket is figyelnünk és rögzítenünk kell, amennyiben pontosabb képet kívánunk kapni a régmúlt idők tbc-gyakoriságáról.

$$
* * *
$$

A tanulmányt Dr. K. Zoffmann Zsuzsanna emlékének ajánljuk. 
Köszönetnyilvánítás: A kutatás a 78555 számú OTKA pályázat és a F/00 094/BL számú Leverhulme Trust Project Grant támogatásával valósult meg. Köszönjük Dr. Horváth Ferencnek (Móra Ferenc Múzeum, Szeged) és Dr. Marcsik Antóniának (SZTE TTIK Embertani Tanszék, Szeged) a vizsgálatok során nyújtott szakmai támogatást.

\section{Irodalom}

Assis, S., Santos, AL., Roberts, C. (2011): Evidence of hypertrophic osteoarthropathy in individuals from the Coimbra Skeletal Identified Collection. Int. J. Paleopathol., 1: 155-163.

Aufderheide, A.C., Rodriguez-Martin, C. (1998): The Cambridge Encyclopedia of Human Paleopathology. Cambridge University Press, Cambridge. p. 133.

Baker, O., Lee, O.Y.C., Wu, H.H.T., Besra, G.S., Minnikin, D.E., Llewellyn, G., Williams, C.M., Maixner, F., O’Sullivan, N., Zink, A., Chamel, B., Khawam, R., Coqueugniot, E., Helmer, D., Le Mort, F., Perrin, P., Gourichon, L., Dutailly, B., Pálfi, Gy., Coqueugniot, H., Dutour, O., (2015): Human tuberculosis predates domestication in ancient Syria. Tuberculosis, 95(S1): S4-12. DOI: 10.1016/j.tube.2015.02.001

Brothwell, D.R. (1989): The relationship of tooth wear to aging. In: İșcan, M.Y. (Ed.) Age Markers in the Human Skeleton. Charles C Thomas, Springfield. p. 303-316.

Canci, A., Minozzi, S., Borgognini Tarli, S.M. (1996): New Evidence of Tuberculous Spondylitis from Neolithic Liguria (Italy). Int. J. Osteoarchaeol., 6: 497-501. DOI: 10.1002/(SICI)10991212(199612)6:5<497::AID-OA291>3.0.CO;2-O

Coros, A., DeConno, E., Derbyshire, K.M. (2008): IS6110, a Mycobacterium tuberculosis complex-specific insertion sequence, is also present in the genome of Mycobacterium smegmatis, suggestive of lateral gene transfer among mycobacterial species. J. Bacteriol., 190(9): 3408-3410. DOI: 10.1128/JB.00009-08

Donoghue, H.D., Lee, O.Y.C., Minnikin, D.E., Besra, G.S., Taylor, J.H., Spigelman, M. (2010): Tuberculosis in Dr Granville's mummy: a molecular re-examination of the earliest known Egyptian mummy to be scientifically examined and given a medical diagnosis. Proc. R. Soc. B., 277: 51-6, DOI: $10.1098 /$ rspb.2009.1484

Donoghue, H.D., Spigelman, M., O’Grady, J., Szikossy, I., Pap, I., Lee, O.Y.C., Wu, H.H.T., Besra, G.S., Minnikin, D.E. (2015): Ancient DNA analysis - An established technique in charting the evolution of tuberculosis and leprosy. Tuberculosis, 95(S1): S140-S144. DOI: 10.1016/j.tube.2015.02.020

Formicola, V., Milanesi, Q., Scarsini, C. (1987): Evidence of spinal tuberculosis at the beginning of the fourth millennium BC From Arene Candide Cave (Liguria, Italy). Am. J. Phys. Anthropol., 72: 1-6. DOI: 10.1002/ajpa.1330720102

Gazdapusztai, G. (1963): Későneolitkori telep és temető Hódmezövásárhely-Gorzsán. A Móra Ferenc Múzeum Évkönyve. p. 21-48.

Gladykowska-Rzeczycka, J.J. (1999): Tuberculosis in the past and present in Poland. In: Pálfi, G., Dutour, O., Deák, J., Hutás, I. (Eds) Tuberculosis: Past and Present. Golden Book Publishers and Tuberculosis Foundation, Budapest - Szeged. p. 561-573.

Hajdu, T., Donoghue, H.D., Bernert, Zs., Fóthi, E., Kővári, I., Marcsik, A. (2012a): A case of spinal tuberculosis from the Middle Ages in Transylvania (Romania). Spine, 37: e1598-601. DOI: 10.1097/BRS.0b013e31827300dc

Hajdu, T., Fóthi, E., Kővári, I., Merczi, M., Molnár, A., Maász, G., Avar, P., Marcsik, A., Márk, L. (2012b): Bone tuberculosis in Roman Period Pannonia (western Hungary). Mem. Inst. Oswaldo Cruz (Rio de Janeiro), 107(8): 1048-1053.

Hershkovitz, I., Donoghue, H.D., Minnikin, D.E., Besra, G.S., Lee, O.Y.C., Gernaey, A.M., Galili, E., Eshed, V., Greenblatt, C.L., Lemma, E., Bar-Gal, G.K., Spigelman, M. (2008): Detection and molecular characterization of 9000 -year-old Mycobacterium tuberculosis from a Neolithic settlement in the Eastern Mediterranean. PLoSOne, 3: e3426. DOI: 10.1371/journal.pone.0003426 
Hershkovitz, I., Greenwald, C.M., Latimer, B., Jellema, L.M., Wish-Baratz, S., Eshed, V., Dutour, O., Rothschild, B.M. (2002): Serpens Endocrania Symmetrica (SES): A new term and a possible clue for identifying intrathoracic disease in skeletal populations. Am. J. Phys. Anthropol., 118: 201-216. DOI: 10.1002/ajpa.10077

Hertelendi, E., Horváth, F. (1992): Radiocarbon chronology of late Neolithic settlements in the Tisza-Maros Region, Hungary. Radiocarbon, 34: 859-866.

Horváth, F. (2005): Gorzsa. Preliminary results of the Excavation of the Neolithic Tell between 1978-1996. In: Bende, L., Lőrinczy, G. (Eds) Hétköznapok Vénuszai. Tornyai János Múzeum, Móra Ferenc Múzeum, Hódmezővásárhely. p. 67-68.

Köhler, K., Pálfi, G., Molnár, E., Zalai-Gaál, I., Osztás, A., Bánffy, E., Kirinó, K., Kiss, K.K., Mende, B.G. (2012): A Late Neolithic case of Pott's disease from Hungary. Int. J. Osteoarchaeol., 24(6): 697-703. DOI: 10.1002/oa.2254

Lee, O.Y.C., Wu, H.H.T., Donoghue, H.D., Spigelman, M., Greenblatt, C.L., Bull, I.D., Rothschild, B.M., Martin, L.D., Minnikin, D.E., Besra, G.S. (2012): Mycobacterium tuberculosis complex lipid virulence factors preserved in the 17,000-year-old skeleton of an extinct bison, Bison antiquus. PLoSOne,7: e41923. DOI: 10.1371/journal.pone.0041923

Loth, S.R., Henneberg, M. (1996): Mandibular ramus flexure: a new morphologic indicator of sexual dimorphism in the human skeleton. Am. J. Phys. Anthropol., 99: 473-485. DOI: 10.1002/(SICI)1096-8644(199603)99:3<473::AID-AJPA8>3.0.CO;2-X

Maczel, M. (2003): On the traces of tuberculosis: Diagnostic criteria of tuberculous affection of the human skeleton and their application in Hungarian and French anthropological series. PhD dissertation. University of La Méditerranée - Aix-Marseilles II, University of Szeged.

Marcsik, A., Molnár, E., Ősz, B., Donoghue, H., Zink, A., Pálfi, Gy. (2009): Adatok a lepra, tuberculosis és syphilis magyarországi paleopatológiájához. Folia Anthropol., 8: 5-34.

Masson, M. (2014): The Osteological evidence of Neolithic populations from the Southern Great Plain of Hungary - An insight into the potential of macroscopic observations for the demographic and pathological analyses of past populations. $\mathrm{PhD}$ dissertation. University of Szeged.

Masson, M., Bereczki, Zs., Molnár, M., Donoghue, H.D., Minnikin, D.E., Lee, O.Y.C., Wu, H.H.T., Besra, G.S., Bull, I.D., Pálfi, Gy. (2015): 7000 year-old tuberculosis cases from Hungary - Osteological and biomolecular evidence. Tuberculosis, 95(S1): S13-17. DOI: 10.1016/j.tube.2015.02.007

Masson, M., Molnár, E., Donoghue, H.D., Besra, G.S., Minnikin, D.E., Wu, H.H.T., Lee, O.Y.C., Bull, I.D., Pálfi, Gy. (2013): Osteological and Biomolecular Evidence of a 7000-year-old case of Hypertrophic Pulmonary Osteopathy secondary to Tuberculosis from Neolithic Hungary. PLoSOne, 8(10): e78252, DOI: 10.1371/journal.pone.0078252

Masson, M., Molnár, E., Pálfi, Gy. (2009): Palaeopathology of a Late Neolithic Population from Southern Hungary. In: Pálfi, Gy., Molnár, E., Bereczki, Z., Pap, I. (Eds) From Past Lesions to Modern Diagnostics. Szeged University Press, Szeged. pp. 80-81.

Matos, V., Santos, A.L. (2006): On the trail of pulmonary tuberculosis based on rib lesions: Results from the human identified skeletal collection from the Museu Bocage (Lisbon, Portugal). Am. J. Phys. Anthropol., 130: 190-200. DOI: 10.1002/ajpa.20309

Mays, S., Taylor, G.M. (2002): Osteological and biomolecular study of two possible cases of hypertrophic osteoarthropathy from Medieval England. J. Archaeol. Sci., 29: 1267-1276. DOI: 10.1006/jasc.2001.0769

Minnikin, D.E., Lee, O.Y-C., Wu, H.H.T., Besra, G.S., Bhatt, A., Nataraja, V., Rothschild, B.M., Spigelman, M., Donoghue, H.D. (2015): Ancient mycobacterial lipids: Key reference biomarkers in charting the evolution of tuberculosis. Tuberculosis, 95(S1): S133-139. DOI: 10.1016/j.tube.2015.02.009

Müller R., Roberts C.A., Brown T.A. (2015): Complications in the study of ancient tuberculosis: non-specificity of IS6110 PCRs. STAR, 1(1): 1-8. DOI: 10.1179/2054892314Y.0000000002 
Munoz, C.H., Vásquez, G.M., González, L.A. (2015): Hypertrophic osteoarthropathy as a complication of pulmonary tuberculosis. Reumatol. Clin., 11: 255-257, DOI: 10.1016/j.reumae.2014.10.003

Ntaios, G., Adamidou, A., Karamitsos, D. (2008): Hypertrophic pulmonary osteoarthropathy secondary to bronchial adenocarcinoma and coexisting pulmonary tuberculosis: a case report. Cases J., 1: 221. DOI: 10.1186/1757-1626-1-221

Ortner, D.J. (2003): Identifications of Pathological Conditions in Human Skeletal Remains. Academic Press, Elsevier Science, San Diego.

Pálfi, Gy., Bereczki, Z., Ortner, D.J., Dutour, O. (2012): Juvenile cases of skeletal tuberculosis from the Terry Anatomical Collection (Smithsonian Institution, Washington, D.C., USA). Acta Biol. Szeged., 56(1): 1-12.

Pálfi, Gy., Dutour, O., Deák, J., Hutás, I. (1999, Eds): Tuberculosis: Past and Present. TB Foundation, Golden Book Publisher, Szeged - Budapest. p. 608.

Pósa, A., Maixner, F., Zink, A., Lovász, G., Molnár, E., Bereczki, Zs., Perrin, P., Dutour, O., Sola, C,. Pálfi, Gy. (2012): Ancient human tooth samples used for TB paleomicrobial research. Acta Biol. Szeged., 56: 125-131.

Pósa, A., Maixner, F., Mende, B.G., Köhler, K., Osztás, A., Sola, C., Dutour, O., Masson, M., Molnár, E., Pálfi, Gy., Zink, A. (2015): Tuberculosis in Late Neolithic - Early Copper Age human skeletal remains from Hungary. Tuberculosis, 95(S1): S18-22. DOI: 10.1016/j.tube.2015.02.011

Redman, J.E., Shaw, M.J., Mallet, A.I., Santos, A.L., Roberts, C., Gernaey, A.M., Minnikin, D.E. (2009): Mycocerosic acid biomarkers for the diagnosis of tuberculosis in the Coimbra Skeletal Collection. Tuberculosis, 89: 267-277. DOI: 10.1016/j.tube.2009.04.001

Reimer, P.J., Baillie, M.G.L., Bard, E., Bayliss, A., Beck, J.W., Blackwell, P.G., Ramsey, C.B., Buck, C.E., Burr, G.S., Edwards, R.L., Friedrich, M., Grootes, P.M., Guilderson, T.P., Hajdas, I., Heaton, T.J., Hogg, A.G., Hughen, K.A., Kaiser, K.F., Kromer, B., McCormac, F.G., Manning, S.W., Reimer, R.W., Richards, D.A., Southon, J.R., Talamo, S., Turney, C.S.M., van der Plicht, J., Weyhenmeyer, C.E. (2009): IntCal09 and Marine09 radiocarbon age calibration curves, 0-50,000 years cal BP. Radiocarbon, 51: 1111-1150.

Rothschild, B.M., Rothschild, C. (1998): Recognition of hypertrophic osteoarthropathy in skeletal remains. J. Rheumatol., 25: 2221-2227.

Schaefer, M.C., Black, S., Scheuer, L. (2009): Juvenile Osteology: A Laboratory and Field Manual. Academic Press.

Spekker, O., Pálfi, Gy., Kozocsay, G., Pósa, A., Bereczki, Zs., Molnár, E. (2012): New cases of probable skeletal tuberculosis from the Neolithic period in Hungary - A morphological study. Acta Biol. Szeged., 56: 115-123.

Webb, J.G., Thomas, P. (1986): Hypertrophic Osteoarthropathy and Pulmonary Tuberculosis. Tubercle, 67: 225-228.

White, T.D., Folkens, P.A. (2005): The Human Bone Manual. Elsevier Press, San Diego.

Zink, A., Molnár, E., Motamedi, N., Pálfi, Gy., Marcsik, A., Nerlich, A.G. (2007): Molecular History of Tuberculosis from Ancient Mummies and Skeletons. Int. J. Osteoarchaeol., 17: 380-391. DOI: 10.1002/oa.909

$\begin{array}{ll}\text { Levelezési cím: } & \text { Muriel Masson } \\ \text { Mailing address: } & \text { SZTE TTIK Embertani Tanszék } \\ & \text { Közép fasor 52. } \\ & \text { H-6726 Szeged } \\ & \text { Hungary } \\ & \text { mmasson@bio.u-szeged.hu }\end{array}$

